\title{
SEKOLAH KHUSUS / SLB MELATI CERIA SAMPIT
}

\author{
Adi Wiratama Manaku \\ Program Studi Teknik Arsitektur Fakultas Teknik Universitas Lambung Mangkurat \\ adiwima559@gmail.com \\ Dila Nadya Andini \\ Program Studi Teknik Arsitektur Fakultas Teknik Universitas Lambung Mangkurat \\ dila.andini@ulm.ac.id
}

\begin{abstract}
ABSTRAK
Menurut World Health Organization (WHO), sekitar 5\% dari populasi dunia - sekitar 466 juta orang diagnosis disebut 'melumpuhkan gangguan pendengaran'. Walaupun statistik ini dibagi menjadi beberapa tingkat ketidakmampuan pendengaran, parsial atau total (gangguan pendengaran atau tunarungu), persentase keseluruhan ditandai dengan gangguan pendengaran yang lebih dari $40 \mathrm{~dB}$ untuk orang dewasa dan lebih dari $30 \mathrm{~dB}$ untuk anak-anak. Pengurangan kapasitas pendengaran memerlukan cara untuk mengalami lingkungan. Dengan pendekatan prinsip-prinsip desain "DeafSpace", yang didasarkan pada pengetahuan lingkungan yang dibangun, sebagian besar dibangun untuk orang-orang yang terganggu pendengaranya, menghadirkan berbagai tantangan yang ditanggapi oleh Tunarungu dengan cara untuk mengubah lingkungan agar mengetahui dengan lingkungan mereka.
\end{abstract}

Kata kunci: Tunarungu, Deaf Space, Pendengaran.

\begin{abstract}
According to the World Health Organization (WHO), approximately 5\% of the world's population around 466 million people - the diagnosis of the so-called 'knock out hearing loss'. Although these statistics are divided into several levels of the inability of the hearing, partial or total (hearing or deaf), the overall percentage is characterized by hearing loss greater than $40 \mathrm{~dB}$ for adults and more than $30 \mathrm{~dB}$ for the kids. The reduction of the capacity of the auditory requires a way to experience the environment. With the approach of the design principles "DeafSpace", which is based on the knowledge of the built environment, mostly built for people who interrupted his hearing, presenting various challenges addressed by the hearing-impaired a way to change the environment in order to know with their environment.
\end{abstract}

Keywords: Deaf, Deafspace, Hearing.

\section{PENDAHULUAN}

Pendidikan merupakan hal penting untuk kehidupan manusia yang bisa didapatkan dari sekolah ataupun kegiatan hidup sehari-hari. Menurut Ency-clopedia Americana, pendidikan adalah segala sesuatu yang bisa didapat oleh intensional, kreatif, sistematis dan etis, diterapkan oleh teknik ilmiah dan metode, untuk mencapai tujuan. Menurut pasal 15 dalam Undang-Undang Sistem Pendidikan Nasional Tahun 2003, pendidikan bisa dibagi beberapa jenis, ialah pendidikan keagamaan , umum, akademik, kejujuran, profesi, khusus dan vokasi.

Anak berkebutuhan khusus merupakan anak dengan rentang usia $5-18$ tahun mempunyai kelainan fisik dan mental yang dapat mengganggu mereka untuk beraktivitas secara layak, 191 
terdiri dari penyandang gangguan fisik, mental. Berdasarkan data Kementerian Pendidikan dan Kebudayaan (Kemendikbud) memperkirakan hampir $70 \%$ anak berkebutuhan khusus tidak memperoleh pendidikan yang layak, dan terdapat 2070 SLB di Indonesia yang terbagi menjadi 545 sekolah negeri dan 1525 sekolah swasta.

\section{PERMASALAHAN}

Berdasar latar belakang diatas, Perumusan masalah yang diharapkan berupa perancangan desain sekolah anak berkebutuhan khusus (ABK) yang dapat menunjang dan meningkatkan daya belajar pada Sekolah Luar Biasa (SLB) Yayasan Melati Ceria Kota Sampit.

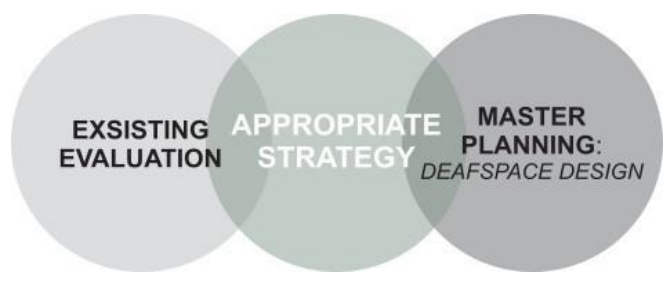

Gambar 1. Pendekatan Penyelesaian Permasalahan

\section{TINJAUAN PUSTAKA}

\section{A. Pengertian Judul}

Dalam karate Menurut Peraturan Menteri Pendidikan Nasional Republik Indonesia Nomor 1 Tahun 2008 Sekolah Luar Biasa (SLB) adalah tempat pendidikan bagi peserta didik yan g me-miliki tingkat kesulitan dalam mengikuti proses pembelajaran karena kelainan fisik, emosional, intelektual, sosial, atau memiliki poten-si kecerdasan dan bakat istimewa.

Pendidikan khusus meliputi peserta didik berkelainan atau peserta didik yang memiliki potensi kecerdasan dan bakat istimewa. Standar proses pendidikan khusus ini, berlaku untuk peserta didik tunanetra, tunarungu, tunagrahita ringan, tunadaksa ringan, tunalaras pada SDLB, SMPLB dan SMALB

termasuk sekolah/madrasah penyelenggara pen-didikan inklusi/terpadu.

Kebutuhan khusus (special needs) bisa dilihat dari keadaan lingkungan sekitar dan kebiasan sehari-hari, maupun kombinasi dari keduanya, sedangkan ditinjau dari sifatnya bisa bersifat sementara (temporer) maupun menetap (permanen). Kalimat sebelumnya bisa didukung dengan sasaran pendidikan luar biasa (special needs education) untuk membantu khususnya terkait dengan hambatan belajar dan perkembangan.

Sehubungan dengan pemahaman baru tentang sasaran didiknya, maka pendidikan luar biasa (special needs education) memiliki fungsi untuk menangani, mengurangi hambatan untuk belajar anak. berkebutuhan khusus \{special needs).

\section{PEMBAHASAN}

\section{A. Lokasi}

Tapak Terletak pada eksisting Yayasan Melati Ceria Sampit menghadap arah Utara yang berhadapan langsung dengan jalan, yaitu di Jalan Wengga Metropolitan Jalur 1 Nomor 33, Kelurahan Baamang Barat, Kecamatan Baamang, Sampit. Luas wilayah perencanaan yang akan diluaskan menjadi $1650 \mathrm{~m} 2$..

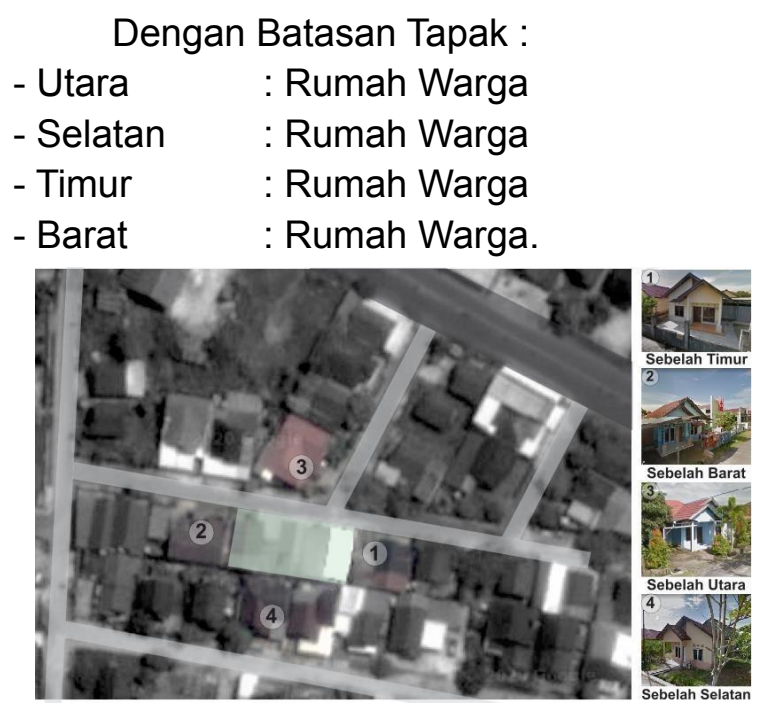

Gambar 2. Batas-Batas Tapak 


\section{B. Konsep Rancangan}

\section{Konsep Rancangan}

Konsepnya programing pada sekolah khusus / SLB Melati Ceria Sampit ini menggunakan prinsip-prinsip deafspace sebagai guideline dengan pendekatan Visual Range terhadap anak berkebutuhan khusus pendengaran.

Berikut grafik prinsip-prinsip deafspace guil-deline.

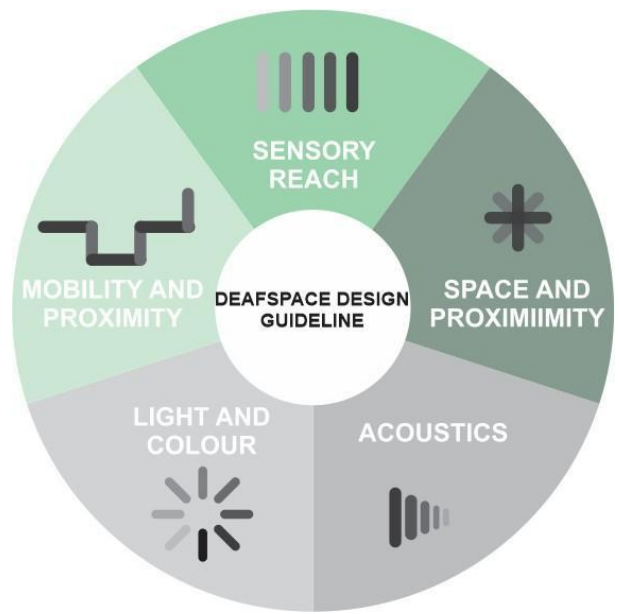

Gambar 3. Deafspace Principles Guideline (Pribadi, 2020)

\section{Konsep Perancangan}

Konsep perancangannya menggunakan prinsip-prinsip desain deafspace sebagai guideline desain pada sekolah khusus / SLB Melati Ceria Sampit menjadi 3 kelompok utama, yaitu:

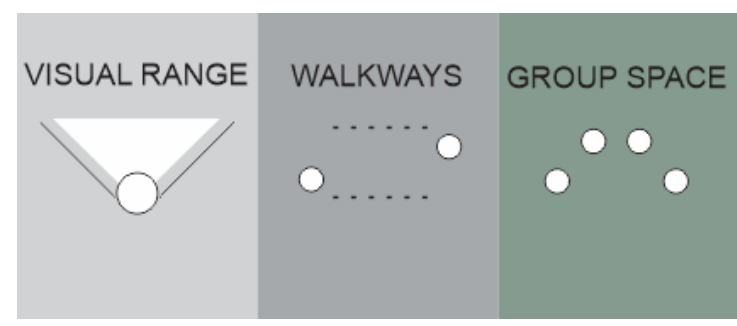

Gambar 4. Pengelompokkan Pada Deafspace Design
3. Konsep Massa Bangunan

Konsep digunakan Berdasarkan hasil analisa internal, kebutuhan,dimensi ruang, ruang, zoning serta paling penting organisasi ruang akan menghasilkan denah rancangan awal seperti gambar di atas

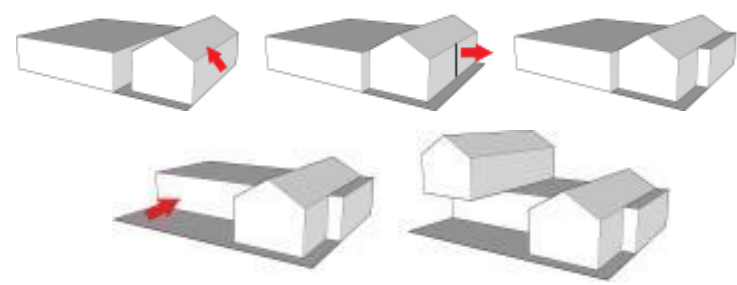

Gambar 4. Konsep Bangunan.

4. Konsep Pencahayaan

Konsep Pencahayaan pada ruang kelas, ruang pembelajaran lainnya menggunakan pencahayaan alami serta bertujuan agar lebih hemat energi. Pencahayaan alami didukung dengan adanya bukaan yang lebar. Namun untuk mengurangi panas matahari yang masuk dengan cahaya, digunakan shading dan filter berupa kisi-kisi pada jendela menggunakan sunscreen

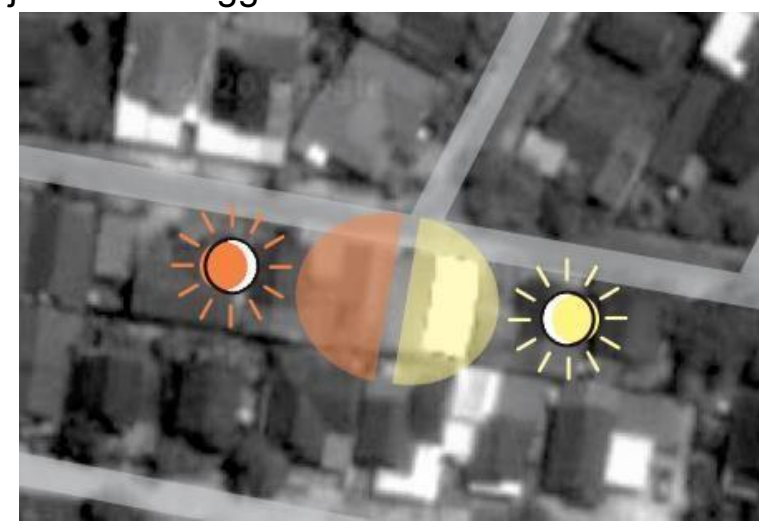

Gambar 5. Analisis Pembayangan Sinar Matahari Pada Tapak

Penggunaan area atau ruang buffer sebagai area penyeimbang serta area pertukaran sirkulasi udara dari luar ke dalam dan dalam ke luar. Pemanfaatan area buffer pada bangunan dapat dimaksimalkan dengan penggunaan secondary skin bagi area yang langsung menghadap bagian barat. 
Penerapan desain menampilkan kedekatan \& hubungan ruang, sirkulasi, material, pencahayaan dan akustik ruang diharapkan meningkatkan proses pembelajaran didalam sekolah tersebut.

Gambar 6. Penggunaan Sunscreen

HASIL

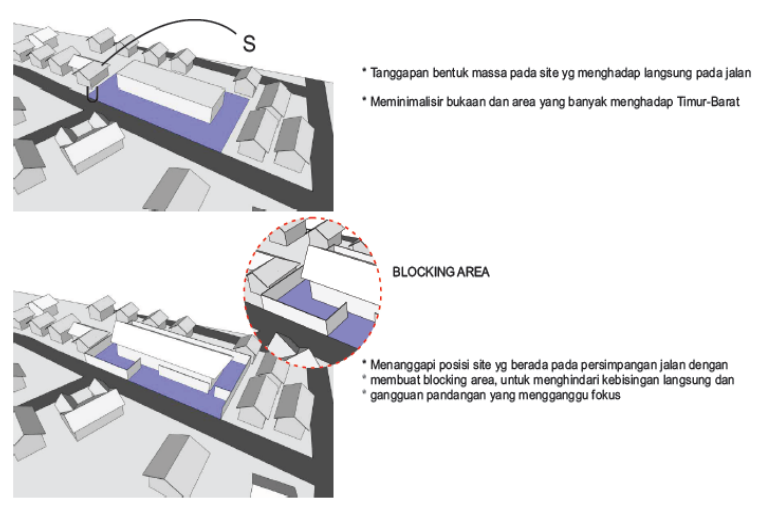

Gambar 7. Perspektif dan Tampak Rancangan.

\section{KESIMPULAN}

Sekolah Melati Ceria merupakan yayasan swasta sebagai salah satu sekolah luar biasa (SLB) untuk penyandang gangguan pendengaran, kekurangan dalam hal pendengaran. Tujuan dari perencanaan kembali sekolah Melati Ceria Sampit merupakan sebuah gagasan terhadap desain bangunan yang belum memenuhi standar bagi pelaksanaan pembelajaran maupun kegiatan belajar. Tinjauan dari permasalahan dan hasil observasi kemudian di angkatlah gagasan ide desain yang menerapkan prinsip-prinsip pada deafspace design tapi memfokuskan Visual Range pada sekolah Melati Ceria Sampit.

Prinsip pada deafspace design merupakan sebuah tanggapan terhadap karakteristik penyandang berkebutuhan khusus atau kekurangan dalam mendengar.

\section{DAFTAR PUSTAKA}

Bauman, H., 2020. DeafSpace: Principles and Elements of DeafSpace. [Online]

Available at: https://infoguides.rit.edu/c.php?g=545353 $\& p=6922725$

Darat, Direktorat Bina Sistem Lalu Lintas Angkutan Kota | Direktorat Jenderal Perhubungan, 1998. Pedoman Perencanaan dan Pengoperasiaan Fasilitas Parkir. Jakarta: s.n.

Designabilities, 2009. Mediating Deaf Experience. [Online]

Available at: https://designabilities.wordpress.com/200 9/06/30/mediating-deaf-experience/

DKa | Dannger Keane Architecture, t.thn. Deafspace Design Guide. [Online]

Available at: http://dangermondkeane.com/projects/dea fspace-design-guide

Gallaudet University, 2013. Gallaudet University Foundation. Request For Qualification, 22 May, p. 14.

Goldchain, M., 2015. MASSIVE 1.1M SQ. FT. PROJECT PLANNED IN NOMA BY GALLAUDET, JBG. [Online]

Available at: http://www.pigmentalstudios.com/news-an d-events/massive-1-1m-sq-ft-project-plan ned-noma-gallaudet-jbg/

Kaplan, S., 2020. Gallaudet University Helps Deaf, Hard of Hearing Stay Informed on Virus. [Online]

Available at: https://m.washingtontimes.com/news/202 
0/apr/2/gallaudet-university-helps-deaf-ha rd-hearing-peopl/

Kementerian Pendidikan dan Kebudayaan, 2017.

[Online]

Available

at:

https://www.kemdikbud.go.id/main/

Neufert, E., 2002. Data Arsitek. Jakarta: Erlangga.

PERMEN PU, M. P. U., 2006. Peraturan Menteri Pekerjaan Umum.

POPMAMA.com, 2019. Ini Daftar Sekolah Luar Biasa untuk Anak Sesuai Tingkat dan Kondisinya. [Online]

Available at: https://www.popmama.com/big-kid/6-9-ye ars-old/tiffany/daftar-sekolah-luar-biasa-u ntuk-anak-sesuai-tingkat-dan-kondisinya/ 4

Pribadi, 2020. Analisa Pribadi. s.I.:s.n.

Wikipedia, 2020. Anak berkebutuhan khusus. [Online]

Available at: https://id.wikipedia.org/wiki/Anak_berkebu tuhan_khusus\#: :text=Klasifikasi\%20tuna rungu $\% 20$ berdasarkan $\% 20$ tingkat $\% 20$ gan gguan $\% 20$ pendengaran\%20adalah\%3A\&t ext=Gangguan $\% 20$ pendengaran $\% 20$ seda ng(56\%2D70,(di\%20atas\%2091\%20dB).

Yayasan Melati Ceria, t.thn. Sampit(Kalimantan Tengah): Yayasan Melati Ceria. 